\title{
Ecosystem effects of bluefin tuna Thunnus thynnus thynnus aquaculture in the NW Mediterranean Sea
}

\author{
F. Forrestal ${ }^{1, *}$, M. Coll ${ }^{2,3,4}$, D. J. Die ${ }^{1}$, V. Christensen ${ }^{3,4}$ \\ ${ }^{1}$ Rosenstiel School of Marine and Atmospheric Science, 4600 Rickenbacker Csy, Miami, Florida 33133, USA \\ ${ }^{2}$ Institut de Ciènces del Mar, ICM-CSIC, Passeig Marítim de la Barceloneta, 37-49, 08003 Barcelona, Spain \\ ${ }^{3}$ Ecopath International Initiative Association, Spain \\ ${ }^{4}$ Fisheries Centre, University of British Columbia, 2202 Main Mall, Vancouver, V6T 1Z4 British Columbia, Canada
}

\begin{abstract}
In recent decades the eastern stock of Atlantic bluefin tuna Thunnus thynnus thynnus has declined, driven by excessive catches partially mediated by the growth of the capturebased aquaculture of bluefin in the Mediterranean. This study addresses the potential direct and indirect food-web effects on trophic linkages in the ecosystem through the removal of both small pelagic fish species and wild bluefin tuna for aquaculture operations in the Mediterranean. A mass-balanced model representing the southern Catalan Sea during the 1990s was modified to include a bluefin tuna farm partially supplied from fish captured in the area modeled. Six scenarios were developed to simulate possible changes to the capture-based aquaculture operations and possible impacts to the ecosystem. The addition of one bluefin tuna farm in the Catalan Sea did not produce substantial effects in the ecosystem. Simulation scenarios that include the level of production already present in a similar ecosystem in the Murcia region resulted in large fluctuations of both biomass and yield for bluefin tuna, as well as for many species in the modeled ecosystem. Increases in biomass of lower trophic level functional groups were observed with reductions in biomass from higher trophic level predators. These outcomes demonstrate that removal of biomass at top and intermediate trophic levels can have direct and indirect outcomes on the structure of the ecosystem due to the complexity of the food web. Our results suggest, in the case of the Western Mediterranean Sea, increasing bluefin tuna farming activities will likely contribute towards further degradation of an already highly exploited ecosystem.
\end{abstract}

KEY WORDS: Capture-based aquaculture $\cdot$ Bluefin tuna $\cdot$ Food-web model Ecopath with Ecosim $\cdot$ Mediterranean Sea

\section{INTRODUCTION}

Capture-based aquaculture of northern Atlantic bluefin tuna Thunnus thynnus thynnus Linnaeus, 1758 is a continuously expanding industry throughout the Mediterranean Sea, largely driven by demand from the lucrative Japanese sashimi market (Miyake et al. 2003, Porch 2005). There are 2 differing methods currently employed: farming and fattening. Bluefin farming utilizes juvenile fish (8 to $20 \mathrm{~kg}$ ) that are kept in pens for up to 2 yr before being har- vested. The fattening method is conducted on a much shorter time scale, 3 to $7 \mathrm{mo}$, and uses larger tuna $(>30 \mathrm{~kg})$. The fattening method, on which the present paper focuses, creates a greater muscle fat content, making this fish highly valued in the Japanese sushi and sashimi market (Mylonas et al. 2010). Two-thirds of the tuna exported to Japan from the Mediterranean Sea come from these capture-based aquaculture operations (Ottolenghi 2004). Currently, there are 63 grow-out operations in the Mediterranean, ranging from the Spanish coasts to Croatia and 
Turkey, with plans for further expansion (Miyake et al. 2003, Mylonas et al. 2010). As most of the tuna used for the farms are caught in the Mediterranean Sea, the International Commission for the Conservation of Atlantic Tunas (ICCAT), the regional fisheries management organization responsible for the conservation of tunas and tuna-like species in the Atlantic Ocean and its adjacent seas, assumes that all Mediterranean farmed tuna belong to the eastern stock of Atlantic bluefin tuna. However, obtaining accurate estimates of these removals from the current stock is complicated by the fact that there is no exact method of determining the amount of the fish stocked in the grow-out cages (Aguado-Gimenez \& Garcia-Garcia 2005, Mylonas et al. 2010).

Tuna fattening has come under extensive criticism for several reasons. The wild stock biomass has dropped precipitously since the 1970s, and there has been an effort by some European Union countries, most notably Monaco, to list the species with the Convention on the Trade of Endangered species (CITES) (MacKenzie et al. 2009, CITES 2010). Moreover, despite considerable research, it is not possible to supply commercial levels of bluefin tuna from hatcheries, so fish destined for cages must come from wild populations (Sawada et al. 2005). The demand for small pelagic fish to feed the tuna in cages is growing, and much of this baitfish comes from outside the Mediterranean Sea, allowing for the possible introduction of invasive species and pathogens, as has already been observed in Australian aquaculture operations (WWF 2005). Furthermore, the increase of fishing on small pelagic fish is posing serious problems in many ecosystems, as small pelagic fish play key ecological roles in many areas (Cury et al. 2000), including the Mediterranean Sea (Coll et al. 2006, 2007, Stergiou et al. 2009).

While single stock/population models have been successful in describing effects of fishing or harvesting on wild or cultured stocks, they cannot show interactions between the target/cultured species and the other species that occupy the ecosystem. These trophic connections between species need to be understood as management decisions, and implementations can have unforeseen effects on other species within the ecosystem in question (Christensen \& Pauly 2004, Christensen \& Maclean 2011). In 2001, The Food and Agriculture Organization of the United Nations (FAO) called for the implementation of an Ecosystem Approach to Fisheries (EAF) as a way to ensure the sustainability of fisheries and aquaculture for all stakeholders (FAO 2003). The ecosystem approach to fisheries management incorporates both traditional stock assessments though single-species modeling as well as ecosystem-based models (EBM) (FAO 2003, Christensen \& Maclean 2011).

Therefore, using an ecosystem-based approach, and aiming at complementing previous analysis on tuna stocks in the Mediterranean Sea, we evaluate here the possible changes posed to a marine ecosystem in the northwestern Mediterranean Sea by (1) the partial removal of a top predator, bluefin tuna, and of small pelagic fish used to partially supply farms that conduct capture-based aquaculture of bluefin tuna, and (2) the addition of captured bluefin tuna into the ecosystem that feed on an external source of food (partially imported to the ecosystem) and that generate an additional source of organic matter waste. The ecosystem effects of apex predator loss and fishery-induced trophic cascades are well documented elsewhere (Jackson et al. 2001, Frank et al. 2005, Casini et al. 2009, Salomon et al. 2010), but to our knowledge they have not been explored for captured-based aquaculture (but see Piroddi 2008).

Our analysis was performed using an ecosystem model that represents a northwestern Mediterranean ecosystem (Coll et al. 2006). Ecosystem models are frequently utilized as a tool for ecosystem-based management strategies (Christensen \& Walters 2004) and have been widely applied to study aquatic ecosystems worldwide (e.g. Palomares et al. 2009) and in the Mediterranean Sea (Coll \& Libralato 2012).

\section{MATERIALS AND METHODS}

\section{Ecological modeling with EwE}

The ecosystem model used here was built using the Ecopath with Ecosim software and approach (EwE) Version 6 (Christensen et al. 2008). EwE is currently the most extensively employed ecosystem modeling software available (Christensen \& Walters 2004, Plagányi 2007, Araujo et al. 2008). It allows the trophic flows between discrete trophic levels, or functional groups, to be described and quantified (Polovina 1984, Walters et al. 1997, Pauly et al. 2000) and combines the theory of classical ecology, food chains and linkages, with the concept of mass balance and energy conservation (Christensen \& Walters 2004). A description of the EwE modeling approach is provided in Appendix 1, including the static model Ecopath, and the temporal dynamic module Ecosim. 


\section{Ecosystem model of the southern Catalan Sea}

The majority of bluefin tuna Thunnus thynnus thynnus farming operations in the northwestern Mediterranean Sea are located in the Murcia region of Spain, which is an oligotrophic open-ocean area of the western Mediterranean, but one operation does exist in the Catalan Sea $(400 \mathrm{~km}$ north of the Murcia region). Both regions share ecological similarities and are subjected to similar human pressures (Coll et al. 2012).

While the EwE has been widely employed to develop ecosystem models of various areas of the Mediterranean Sea, these models are generally in enclosed and coastal areas (Coll \& Libralato 2012). The southern Catalan Sea model (Coll et al. 2006), however, represents an area that closely resembles the area of Murcia where current bluefin tuna farming is carried out and was therefore chosen as the ecosystem model for the present study (Fig. 1). This model represents the ecosystem in 1994 to 1995 and describes the continental shelf and upper slope ecosystem of $4500 \mathrm{~km}^{2}$ associated with the Ebro River Delta. It is largely an oligotrophic environment, with depths ranging from 50 to $400 \mathrm{~m}$. Changes to the ecosystem since 1978 were fully examined in Coll et al. (2008).

The original ecological model comprised 40 functional groups (that include single species, groups of species and developmental phases of species), spanning the main trophic components of the ecosystem from primary producers to top predators and including 2 detritus groups (natural detritus and discards from fishing activities). The main fishing activities by operational fleets in the area were also included, i.e. the bottom-trawling, purse-seine, long-line and trollbait fleets. Migratory patterns of bluefin tuna were taken into account within the original and modified

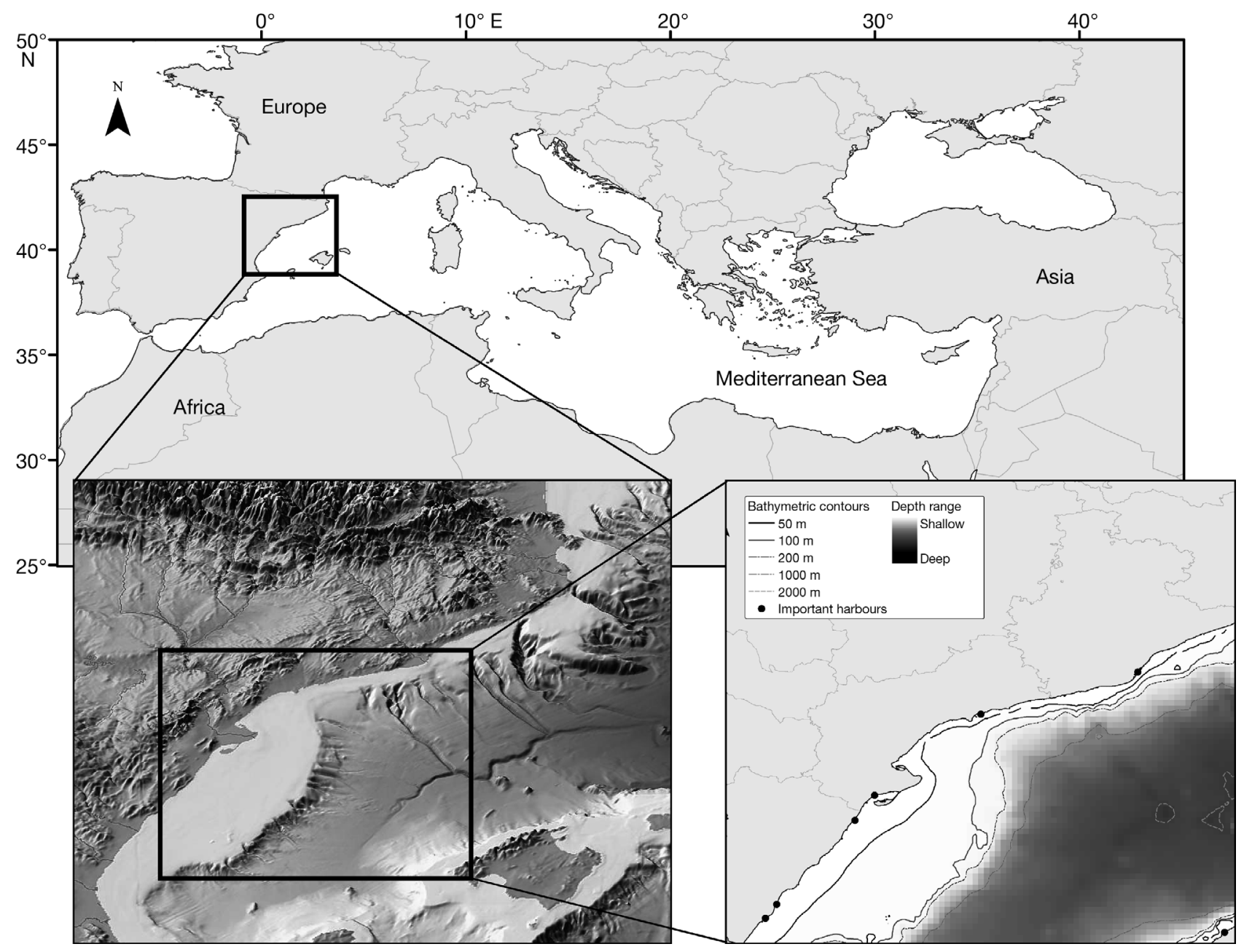

Fig. 1. The NW Mediterranean Sea and the southern Catalan Sea study area (modified from Catalano-Balearic Sea bathymetric chart 2005, Institute of Marine Science [ICM-CSIC], Barcelona, Spain) 
model by modeling a proportion of the diet composition of these groups as imports to the system and by describing a migratory flux of production in the area (see Coll et al. 2006, 2008 for further details). This model was fitted to time series of data from 1978 to 2003 to validate the static food-web model and its hindcasting capabilities (Coll et al. 2008).

\section{Model modifications to incorporate bluefin tuna aquaculture}

The existing ecological EwE model (Coll et al. 2006) was modified to accommodate an additional bluefin tuna capture-based aquaculture activity (and the model is named here 'tuna model') (Table 1). We assumed that bluefin tuna used to supply the cages were sourced from the modeled area since wild bluefin tuna was included in the original model and had been parameterized as part of a larger migrating stock (Coll et al. 2006). Additionally, the bait fish species designated as the feed species were assumed to also be initially sourced from the Catalan Sea, a source that was limited by the total biomass of small pelagic fish included in the ecological model and the predation and consumption occurring in the ecosystem (Fig. 2). The limitations imposed by these simplifying assumptions about the sourcing of bluefin tuna, the sourcing of baitfish and the use of a Catalan Sea model, on the interpretation of our results are discussed elsewhere in the paper.

Several scenarios were explored to examine the array of possible ecosystem impacts of tuna farms that may occur in an oligotrophic ecosystem of the northwestern Mediterranean Sea. We began the simulations including only one cage of capture-based bluefin tuna (bluefin tuna farm) in the ecosystem (which would represent the baseline situation that existed in 1995 in Murcia), and then examined various alternatives of increase of this activity in the ecosystem.
The initial model was initially parameterized to include a single bluefin tuna farm, considered in the model to be a separate functional group: 'farmed tuna'. In subsequent Ecosim runs, the numbers of cages were increased. The feed for the farmed group of tuna was set in the diet composition matrix to

Table 1. Southern Catalan food-web model (from Coll et al. 2006), modified to include tuna aquaculture in the ecosystem (shaded rows). Group number corresponds to functional groups in the modified model. $P / B$ : production/biomass ratio $\left(\mathrm{yr}^{-1}\right) ; Q / B$ : consumption/biomass ratio $\left(\mathrm{yr}^{-1}\right) ; E E$ : ecotrophic efficiency; $P / Q$ : production/consumption ratio or gross efficiency; TL: trophic level

\begin{tabular}{|c|c|c|c|c|c|c|c|}
\hline & Group name & Biomass & $P / B$ & $Q / B$ & $E E$ & $P / Q$ & TL \\
\hline 1 & Phytoplankton & 10.20 & 154.61 & - & 0.20 & - & 1 \\
\hline 2 & $\begin{array}{l}\text { Micro- and } \\
\text { mesozooplankton }\end{array}$ & 9.86 & 20.87 & 48.85 & 0.66 & 0.43 & 2.05 \\
\hline 3 & Macrozooplankton & 0.54 & 20.41 & 50.94 & 0.91 & 0.40 & 2.77 \\
\hline 4 & Jellyfish & 0.39 & 13.87 & 50.48 & 0.22 & 0.27 & 2.83 \\
\hline 5 & Suprabenthos & 0.05 & 8.05 & 52.12 & 0.93 & 0.15 & 2.11 \\
\hline 6 & Polychaetes & 15.54 & 1.82 & 11.53 & 0.32 & 0.16 & 2 \\
\hline 7 & Shrimps & 0.05 & 3.08 & 7.20 & 0.95 & 0.43 & 2.98 \\
\hline 8 & Crabs & 0.15 & 2.10 & 4.73 & 0.97 & 0.44 & 2.89 \\
\hline 9 & Norway lobster & 0.04 & 1.20 & 4.56 & 0.98 & 0.26 & 2.82 \\
\hline 10 & Benthic invertebrates & 8.87 & 1.02 & 3.13 & 0.43 & 0.33 & 2.02 \\
\hline 11 & Benthic cephalopods & 0.21 & 2.34 & 5.30 & 0.94 & 0.44 & 3.1 \\
\hline 12 & $\begin{array}{l}\text { Benthopelagic } \\
\text { cephalopods }\end{array}$ & 0.20 & 2.06 & 26.47 & 0.83 & 0.08 & 3.67 \\
\hline 13 & Mullets & 0.06 & 2.29 & 6.90 & 0.97 & 0.33 & 3.16 \\
\hline 14 & Conger eel & 0.06 & 1.40 & 3.50 & 0.94 & 0.40 & 4.22 \\
\hline 15 & Anglerfish & 0.05 & 1.40 & 3.50 & 0.97 & 0.40 & 4.39 \\
\hline 16 & Flatfishes & 0.04 & 2.10 & 7.53 & 0.98 & 0.28 & 3.2 \\
\hline 17 & Poor cod & 0.03 & 1.52 & 6.97 & 0.95 & 0.22 & 3.31 \\
\hline 18 & Juvenile hake & 0.04 & 1.30 & 7.37 & 0.93 & 0.18 & 3.45 \\
\hline 19 & Adult hake & 0.35 & 0.60 & 2.52 & 0.98 & 0.24 & 4.1 \\
\hline 20 & Blue whiting & 1.17 & 0.66 & 5.93 & 0.90 & 0.11 & 3.4 \\
\hline 21 & Demersal fishes (1) & 0.52 & 1.16 & 6.85 & 0.98 & 0.17 & 3.08 \\
\hline 22 & Demersal fishes (2) & 0.03 & 1.00 & 7.17 & 0.88 & 0.14 & 3.01 \\
\hline 23 & Demersal fishes (3) & 0.14 & 0.43 & 6.25 & 0.97 & 0.07 & 3.96 \\
\hline 24 & Demersal sharks & 0.06 & 0.42 & 5.43 & 0.91 & 0.08 & 3.68 \\
\hline 25 & Benthopelagic fishes & 0.22 & 1.37 & 9.03 & 0.91 & 0.15 & 3.49 \\
\hline 26 & European anchovy & 2.64 & 1.33 & 13.91 & 0.93 & 0.10 & 3.05 \\
\hline 27 & European pilchard & 3.58 & 1.50 & 8.86 & 0.97 & 0.17 & 2.97 \\
\hline 28 & $\begin{array}{l}\text { Other small pelagic } \\
\text { fishes }\end{array}$ & 0.92 & 0.52 & 7.39 & 1.00 & 0.07 & 3 \\
\hline 29 & Horse mackerel & 1.55 & 0.39 & 5.13 & 0.39 & 0.08 & 3.19 \\
\hline 30 & Mackerel & 0.61 & 0.46 & 4.88 & 0.69 & 0.09 & 3.55 \\
\hline 31 & Atlantic bonito & 0.27 & 0.35 & 4.36 & 0.13 & 0.08 & 4.06 \\
\hline 32 & Swordfish & 0.02 & 0.36 & 1.76 & 0.42 & 0.20 & 4.04 \\
\hline 33 & Farmed tuna & 0.03 & 0.27 & 7.06 & 0.00 & 0.04 & 4.2 \\
\hline 34 & Tuna & 0.12 & 0.26 & 1.63 & 0.90 & 0.16 & 4.5 \\
\hline 35 & Loggerhead turtles & 0.03 & 0.15 & 2.54 & 0.05 & 0.06 & 2.54 \\
\hline 36 & Audouins gull & 0.00 & 4.64 & 70.00 & 0.00 & 0.07 & 3.22 \\
\hline 37 & Other sea birds & 0.00 & 4.56 & 73.20 & 0.33 & 0.06 & 2.19 \\
\hline 38 & Dolphins & 0.00 & 0.07 & 13.49 & 0.14 & 0.01 & 4.33 \\
\hline 39 & Fin whale & 0.36 & 0.04 & 4.11 & 0.00 & 0.01 & 3.81 \\
\hline 40 & Discards 1 & 0.38 & - & - & 0.51 & - & - \\
\hline 41 & Discards 2 & 0.00 & - & - & 0.00 & - & - \\
\hline 42 & Fish farm feed & 0.00 & - & - & - & & - \\
\hline 43 & Detritus & 70.00 & - & - & 0.22 & - & - \\
\hline
\end{tabular}




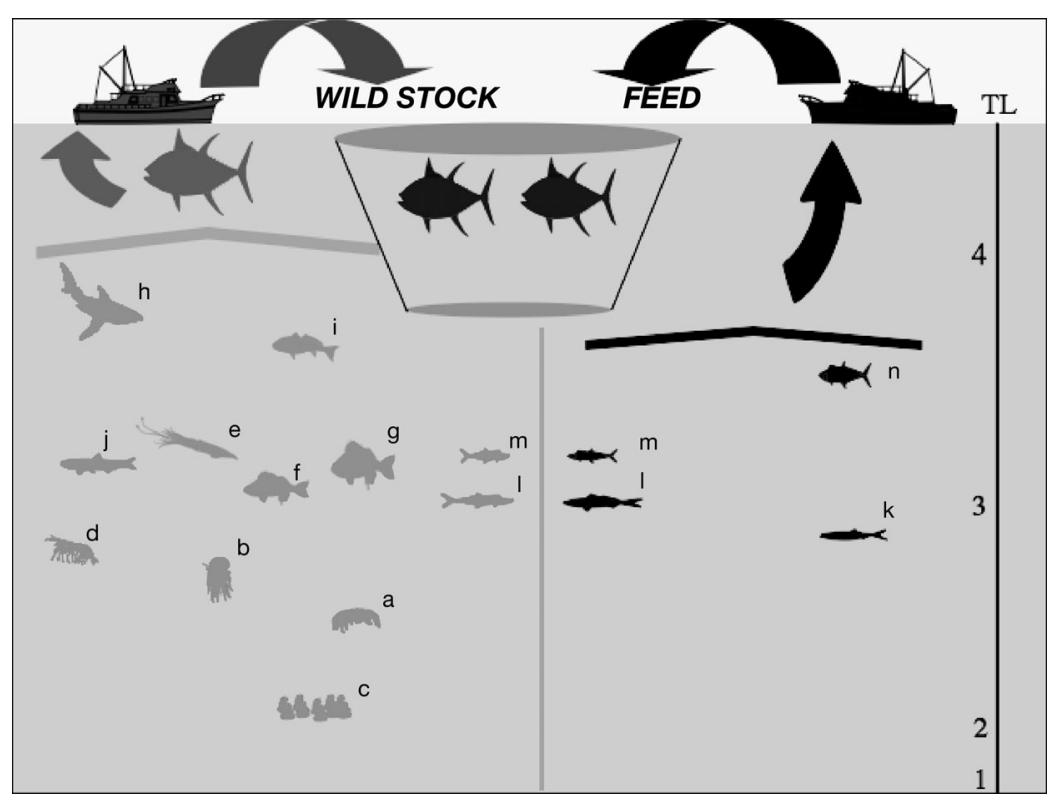

Fig. 2. Connections between wild tuna, caged tuna, tuna and tuna-feed fleets, and the prey that both tuna groups depend on. Vertical axis represents trophic level (TL) (not depth). Black characters (right) represent the feed fishery components, and grey characters (left) represent the wild stock components (left). Letters designate feed and prey functional groups. a: macrozooplankton; b: jellyfish; c: suprabenthos; d: shrimps; e: benthopelagic cephalopods; f: demersal fishes 1; g: demersal fishes 2; h: demersal sharks; i: benthopelagic fishes; $\mathrm{j}$ : European anchovies; k: European pilchards; l: other small pelagic fishes; $\mathrm{m}$ : horse mackerel; $\mathrm{n}$ : mackerel

solely come from the discard group 'fish farm feed' (Table 2). Biomass estimates in the floating cage were calculated from Aguado et al. (2004) from research on a bluefin tuna cage in southeastern Spain. The initial and final weights of 2500 bluefin tuna

Table 2. Diet composition matrix for the 'tuna model' as modified from the original model (Coll et al. 2006). The diet composition is expressed in relative terms (and sums to 1)

\begin{tabular}{|lcc|}
\hline Prey/feed species & Wild tuna & Farm tuna \\
\hline Macrozooplankton & 0.006 & 0.000 \\
Jellyfish & 0.002 & 0.000 \\
Suprabenthos & 0.001 & 0.000 \\
Shrimps & 0.005 & 0.000 \\
Benthopelagic cephalopods & 0.395 & 0.000 \\
Demersal fishes (1) & 0.012 & 0.000 \\
Demersal fishes (2) & 0.012 & 0.000 \\
Demersal sharks & 0.003 & 0.000 \\
Benthopelagic fishes & 0.004 & 0.000 \\
European anchovy & 0.006 & 0.000 \\
European pilchard & 0.000 & 0.035 \\
Other small pelagic fishes & 0.046 & 0.407 \\
Horse mackerel & 0.080 & 0.276 \\
Mackerel & 0.000 & 0.276 \\
Import & 0.431 & 0.007 \\
Sum & 1.000 & 1.000 \\
\hline
\end{tabular}

were sampled from the floating cage over a $90 \mathrm{~d}$ period, the period that individual bluefin tuna spend inside the cage before being harvested. The mean initial weight of a tuna in the cage at their arrival was $180 \mathrm{~kg}$ (and the mean final weight was $193 \mathrm{~kg}$; Aguado et al. 2004). The mean biomass of the bluefin tuna was used to calculate the biomass for the tuna model including 1 cage with 2500 fish, an initial biomass of $450 \mathrm{t}$ and an ending biomass of $482.5 \mathrm{t}$. As the ecological model uses annual consumption and production rates, and bluefin tuna remained in the cage an average of $3 \mathrm{mo} \mathrm{yr}^{-1}$, the biomass of caged bluefin tuna in the model was scaled down to $3 / 12$ of the biomass in the cage, with a total biomass of $0.026 \mathrm{t} \mathrm{km}^{-2} \mathrm{yr}^{-1}$. For comparison, the wild bluefin tuna are in the ecosystem for $5 \mathrm{mo}$, as a result of their migration patterns (Coll et al. 2006, 2008).

The bluefin tuna in the Aguado et al. (2004) study were fed ad libitum with a mixture of small frozen pelagics, mackerel Scomber japonicus, herring Clupea harengus, European sardine Sardina pilchards and sardinella Sardinella aurita in a weight ratio of 12:8:0.75:1. This ratio reflects market availability of prey species and not solely nutritional requirements (Aguado et al. 2004). In our tuna model, the functional groups representing mackerel, horse mackerel, European sardine and 'other small pelagic fishes' were assigned as partial feed to supply the new farmed tuna functional group (Table 2). Horse mackerel was included as one of the feed species for farmed tuna in the model because this species is often marketed together with mackerel in Mediterranean fish markets (M. Coll pers. obs.), thus it was considered as a fish substitute for mackerels in the feed. Feed amounts were scaled to the model area and parameterized into the model as a special fishery labeled 'tuna farm feed'. All catches of this fleet were labeled as a discard group called 'fish farm feed', which fed the 'farmed tuna' group. In addition, an import to the 'fish farm feed' group was created to simulate the supply of tuna feed from outside the area (as the supply from the study region could not support the full development of the increasing aquaculture activities). The 'tuna farm feed' fishery was created to provide a mechanism to allow transfer of 
feed biomass to the farm in a way that was consistent with the Ecosim equations (Appendix 1).

For the bluefin tuna in the cage, the exact production was known empirically from cage studies (Aguado-Gimenez et al. 2006). Therefore, the production/biomass $(P / B)$ ratio was computed as the increase in weight during the fattening period over the mean biomass of the bluefin tuna in the cages. This was then converted into the unit of a year for the model $\left(0.275 \mathrm{yr}^{-1}\right)$. Since the consumption of the bluefin tuna in the cages is known (Aguado-Gimenez et al. 2006), the consumption/biomass $(Q / B)$ ratio was calculated directly from cage observations. The total amount of feed provided to bluefin tuna was $840 \mathrm{t}$ during the $90 \mathrm{~d}$ period that they spend in the cage $\left(7.062 \mathrm{yr}^{-1}\right)$. Divers monitoring the feeding activities estimated that for every $1 \mathrm{~kg}$ of feed, $10 \mathrm{~g}$ was lost to the water column (Aguado et al. 2004).

We adjusted the estimated consumption over the $90 \mathrm{~d}$ period to the average biomass in the cage because biomass changes over the period as fish increases in weight. From that, a daily $Q / B$ was calculated. As for all other functional groups in the model, $P / B$ and $Q / B$ ratios for farmed tuna were assumed to be the ones from the original model (Coll et al. 2006), while the initial group of tuna and swordfish was split to separate both species.

Regarding catches from the 'tuna farm feed' and in order to start with a balanced model, $0.0012 \mathrm{t} \mathrm{km}^{-2}$ $\mathrm{yr}^{-1}$ of the small pelagic fish had to be sourced from outside the model so some 'tuna farm feed' had to be imported into the system. Parameterization of the initial model yielded a fish farm feed ecotrophic efficiency $(E E)$ of 0.930 , corresponding to a loss of approximately $7 \%$ to the system. The small amount of unconsumed feed is the result of close monitoring of the bluefin tuna by SCUBA divers during feeding and the cessation of supplying feed to the cage when signs of satiation are seen (Aguado-Gimenez \& Garcia-Garcia 2005).

\section{Simulations of bluefin tuna aquaculture with Ecosim}

Various simulations of bluefin tuna aquaculture using the temporal dynamic module Ecosim (Walters et al. 1997, Christensen \& Walters 2004) were developed to represent plausible alternatives for the evolution of bluefin tuna farming within the current context of management for the stock of eastern Atlantic bluefin tuna in the Mediterranean Sea. The base tuna model represented the ecosystem in 1994 to 1995, and all scenarios forecasted the ecosystem dynamics until 2030, i.e. for 35 yr. Scenarios were run modifying the biomass of bluefin tuna inside the cages and the associated demand for wild feed and wild tuna from the ecosystem (Table 3, Fig. 3). Ecosim simulations are especially sensitive to the 'vulnerability' settings, which incorporate densitydependency and express how far a group is from its carrying capacity (Christensen \& Walters 2004, Christensen et al. 2008). Therefore, fitting the model to data is advised before performing simulations, and during our simulations we maintained the vulnerabilities from the fitting.

To provide a baseline for comparison of changes to the ecosystem caused by tuna farming, 2 Ecosim baseline models were run. During the first scenario, Baseline Model 1 (named 'Catalan Sea original'; the Catalan model without tuna aquaculture) extended the initial Ecopath values without modifications until 2030, with fishing effort constant and equal to the values in 1994 to 1995 for all fleets. The second scenario, Baseline Model 2 (named 'One cage') differed in that one tuna cage was introduced in 1994 and

Table 3. Scenarios of bluefin tuna aquaculture developed during the study (see Fig. 3 for further details of scenario inputs). 'Tuna farm' designates when changes to the farm take effect. Fishery designates 4 fisheries unrelated to tuna farm operations, with values from either 1994 or 2003

\begin{tabular}{|lllccc|}
\hline Scenario & Name & Description & Tuna farm & No. of tuna cages & Fishery \\
\hline Baseline 1 & Catalan Sea original & No tuna farming & - & 0 & 1994 \\
Baseline 2 & One cage & One tuna cage, no increases & 1994 & 1 & 1994 \\
Scenario 3 & Current levels & Current levels of cages & 2010 & 48 \\
& of tuna cages & with no outside fishery & & 48 \\
Scenario 4 & Current levels of tuna & Same as Scenario 3, but with & 2010 & 2003 \\
& cages and fishing & 2003 levels of fishing effort & & 16 \\
Scenario 5 & ICCAT 1 & Current management & $1 / 3$ of 2010 level & 32 \\
Scenario 6 & ICCAT 2 & Moderate management & $2 / 3$ of 2010 level & 2003 \\
\hline
\end{tabular}



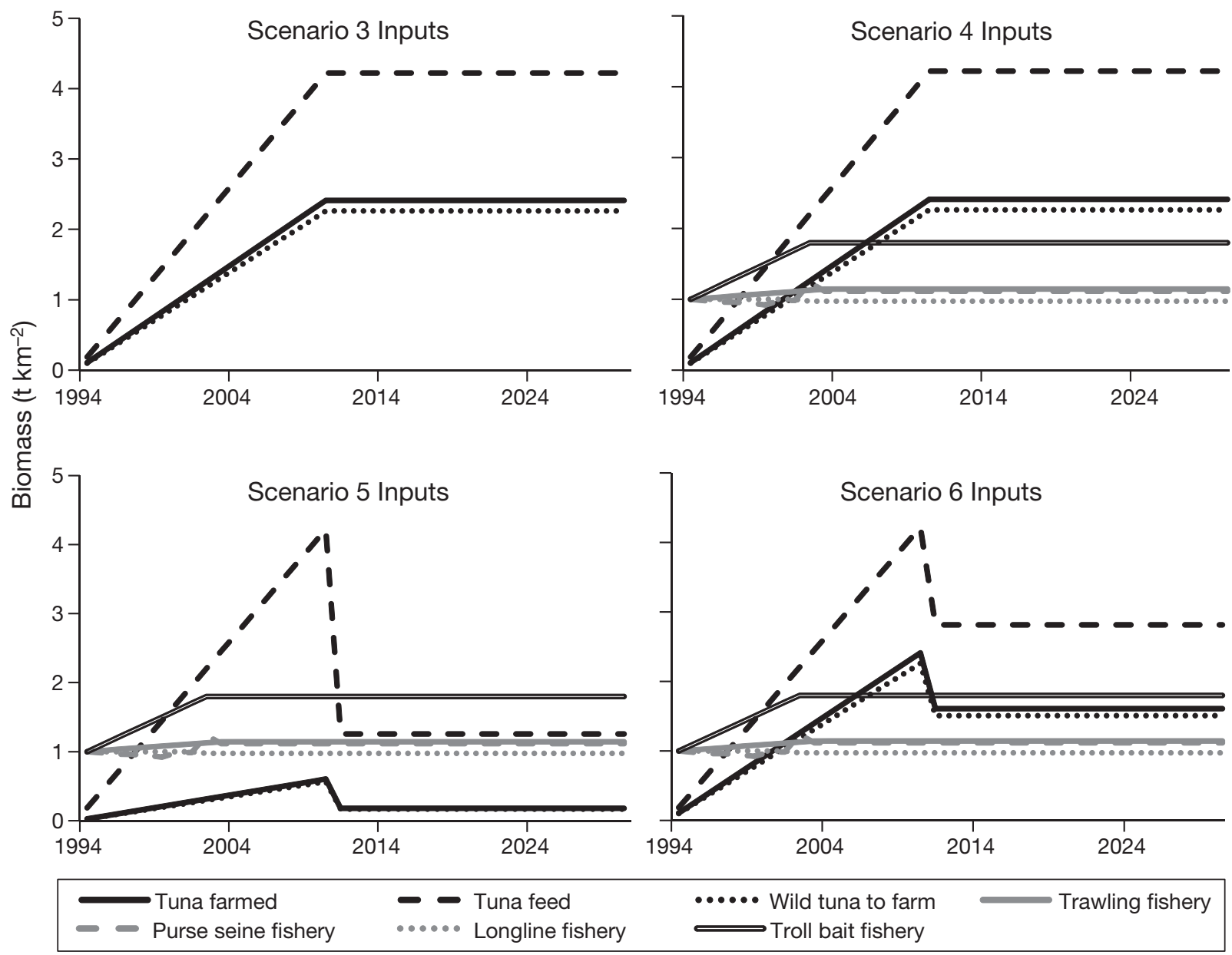

Fig. 3. Scenarios of bluefin tuna aquaculture developed during the present study (see Table 3 for further details of scenario inputs)

operated until 2030. This model included the addition of a fleet dedicated to catching tuna to supply the cage and the transfer of part of the catch from other existing fleets to supply the appropriate feed to the cage at the rates reported by Aguado et al. (2004).

Scenario 3 ('Current levels of tuna cages with no outside fishery ' scenario; Table 3, Fig. 3) represented the development of tuna farming in southeastern Spain, which reached an annual capacity of $10852 \mathrm{t}$ of tuna with 48 cages by 2010 (ICCAT 2011). In this scenario the number of cages evolved from 1 cage in 1994 to 48 cages in 2010 and thereafter. The wild fishery for tuna that supplied the cages and the tuna feed quantities grew according to the needs of caged tuna. In this scenario, fishing effort in all other fleets was kept at the same level as that of 1994.

Scenario 4 ('Current levels of tuna cages and fishing' scenario) differed from Scenario 3 in that fishing effort for the rest of the fishing fleets in- creased from 1994 until 2003 according to the data provided by Coll et al. (2008) and was kept constant afterwards. In Scenario 4 and all subsequent scenarios, fishing effort remained constant and equal to the 2003 levels for the period 2004 to 2030 for all fleets, except for the fleet that supplied tuna for the cages. Therefore, fishing effort in all these scenarios was kept constant from 2004 to 2030 to help separate the effects of aquaculture development from those of changes in overall fishing pressure (Table 3, Fig. 3).

Scenarios 5 and 6 represented different levels of tuna farming from 2010 until 2030 by considering the newest management recommendations of the ICCAT (ICCAT 2011). Catches of bluefin tuna prior to 2010 were well in excess of the estimated maximum sustainable yield of $15000 \mathrm{t}$ and of the total allowable catch (TAC) that had been set to $25000 \mathrm{t}$ (ICCAT 2011). Such catches allowed the development of farmed culture at the levels reported for southeastern 
Spain in 2010. Any reductions in catches required to rebuild the stock are likely to reduce the amount of tuna available for the cages. Scenario 5 ('ICCAT 1') represented the largest reduction in catches of bluefin tuna and reflects the newest TAC set by the ICCAT in 2011 of 12900 t. Scenario 6 ('ICCAT 2') represented a one-third reduction in the tuna put in cages. Such a decrease mirrors a reduction in the TAC to the $13500 \mathrm{t}$ agreed upon by the ICCAT in 2010. While the TAC was reduced in 2011, it is possible that it is being exceeded, and this scenario simulates that occurrence.

\section{Model analysis}

Changes in biomass and catch were analyzed from each Ecosim scenario. Biomass data for the different functional groups in the model were compared for all scenarios by contrasting starting values from 1994 and ending values from 2030. To analyze major changes occurring in the ecosystem during the period 1994 to 2030 those functional groups that suffered an increase or decrease in biomass $>25 \%$ were highlighted. Biomass levels were also analyzed by grouping functional groups into integer trophic level ranges: II-III, III-IV and >IV. Yield data from the Ecosim scenarios were compared in a similar manner.

In addition, ecosystem indicators were also included to compare results from each scenario. These indicators included total biomass ( $\mathrm{TB}, \mathrm{t} \mathrm{km}^{-2}$ ) and total catch ( $\mathrm{TC}, \mathrm{t} \mathrm{km}^{-2} \mathrm{yr}^{-1}$ ), and network analysis such as the total system throughput (TST, $\mathrm{t} \mathrm{km}^{-2}$ $\left.\mathrm{yr}^{-1}\right)$, overall flows $\left(\mathrm{OF}, \mathrm{t} \mathrm{km}^{-2} \mathrm{yr}^{-1}\right)$, the Finn cycling index (FCI, \%) and path length (PL), export (E, $\left.\mathrm{t} \mathrm{km}^{-2} \mathrm{yr}^{-1}\right)$, respiration $\left(\mathrm{R}, \mathrm{t} \mathrm{km}^{-2} \mathrm{yr}^{-1}\right)$, primary production ( $\mathrm{PP}, \mathrm{t} \mathrm{km}^{-2} \mathrm{yr}^{-1}$ ), total production (TP, $\mathrm{t} \mathrm{km}^{-2}$ $\mathrm{yr}^{-1}$ ), proportion of flows to detritus (FD) and ascendency (A) (Christensen et al. 2008). Changes to ecosystem indicators were compared with the trends that would be expected from an ecosystem undergoing degradation.

\section{RESULTS}

\section{Biomass changes}

Of the 39 living functional groups in our tuna model, 16 groups showed changes in biomass $>25 \%$ in one or more of the scenarios (Table 4). Changes in biomass over time for each scenario are shown in
Fig. 4, represented as changes from Baselines 1 and 2. In Scenario 3 ('Current levels of tuna cages with no outside fishery'; Fig. 3, Table 3), 8 functional groups exhibited a biomass change $>25 \%$, with the mackerel group coming close to collapse, at an $85 \%$ reduction in biomass. Conger eels, benthopelagic fish and wild bluefin tuna increased substantially. Other species that experienced a reduction in biomass $>25 \%$ included other small pelagic fish, horse mackerel, Atlantic bonito and swordfish.

Scenario 4 ('Current levels of tuna cages and fishing'; Fig. 3, Table 3) exhibited a larger number of functional groups showing a $>25 \%$ change in their biomass than Scenario 3, which is to be expected as this scenario had additional harvest pressures in place through the presence of the 4 fishing fleets (Table 4). Five functional groups had an increase of $>25 \%$ in biomass: macrozooplankton, Norway lobster, conger eel and benthopelagic fishes. Eight functional groups substantially decreased in biomass: mullets, anglerfish, other small pelagic fish, horse mackerel, mackerel, Atlantic bonito, swordfish and wild bluefin tuna.

In contrast, Scenario 5 ('ICCAT 1'; Fig. 3, Table 3) showed only 5 functional groups that experienced a change in biomass $>25 \%$. Of these, one group had an increase in biomass: conger eels. Mullets, anglerfish, swordfish and wild bluefin tuna decreased.

Under Scenario 6 ('ICCAT 2'; Fig. 3, Table 3) we could observe a total of 8 functional groups with changes in biomass $>25 \%$. Two functional groups had an increase in biomass: Norway lobster and conger eel. Six functional groups had a reduction in biomass: mullets, anglerfish, mackerel, Atlantic bonito, swordfish and bluefin tuna.

\section{Changes in catches}

Fig. 5 represents those catch changes where functional groups decrease or increase by $>25 \%$ in one or more scenarios. In the majority of functional groups, Baselines 1 and 2 have identical yields, with the exception of small differences in yield for pelagic fish, horse mackerel, mackerel and wild bluefin tuna. This is a result of these functional groups having a fishery associated with them in the base model with one tuna cage (Baseline 2) in order to supply the tuna cage.

In general, changes in the yield of the functional group mirrored the changes in the biomass of that functional group (Fig. 4); however, this was not the 
Table 4. Biomass percent changes (+/-) for all functional groups and scenarios (including baselines) (also see Fig. 3). Grey shading highlights functional groups that experienced a $>25 \%$ change in one or more scenario

\begin{tabular}{|c|c|c|c|c|c|c|}
\hline Group name & Baseline 1 & Baseline 2 & Scenario 3 & Scenario 4 & Scenario 5 & Scenario 6 \\
\hline Phytoplankton & - & - & -0.05 & -0.78 & -0.80 & -0.70 \\
\hline Micro- and mesozooplankton & - & - & -0.09 & +1.71 & +2.01 & +1.64 \\
\hline Macrozooplankton & - & - & +20.97 & +27.29 & +8.88 & +17.39 \\
\hline Jellyfish & - & - & -0.16 & +4.18 & +4.82 & +3.97 \\
\hline Suprabenthos & - & - & +4.32 & +17.59 & +13.98 & +15.90 \\
\hline Polychaetes & - & - & -0.44 & -0.88 & -0.12 & -0.20 \\
\hline Shrimps & - & - & +9.58 & +24.78 & +14.90 & +18.72 \\
\hline Crabs & $1.52 \mathrm{E}-03$ & $1.52 \mathrm{E}-03$ & +5.57 & +3.46 & -2.81 & +0.26 \\
\hline Norway lobster & - & - & +18.45 & +37.00 & +18.23 & +25.53 \\
\hline Benthic invertebrates & $9.24 \mathrm{E}-04$ & $8.23 \mathrm{E}-04$ & +2.74 & +2.36 & -0.09 & +1.42 \\
\hline Benthic cephalopods & $5.24 \mathrm{E}-03$ & $5.10 \mathrm{E}-03$ & +6.62 & -6.26 & -11.10 & -7.61 \\
\hline Benthopelagic cephalopods & - & - & +5.71 & +4.36 & -2.52 & -1.56 \\
\hline Mullets & $3.81 \mathrm{E}-03$ & $3.75 \mathrm{E}-03$ & +2.78 & -39.96 & -43.29 & -41.38 \\
\hline Conger eel & $3.99 \mathrm{E}-03$ & $4.24 \mathrm{E}-03$ & +28.77 & +48.29 & +25.61 & +37.06 \\
\hline Anglerfish & $5.68 \mathrm{E}-03$ & $5.64 \mathrm{E}-03$ & +12.35 & -46.15 & -55.39 & -50.71 \\
\hline Flatfishes & $3.44 \mathrm{E}-03$ & $3.32 \mathrm{E}-03$ & +5.92 & +3.24 & -0.28 & +1.76 \\
\hline Poor cod & $9.83 E-03$ & $9.50 \mathrm{E}-03$ & +2.61 & -15.15 & -14.67 & -11.58 \\
\hline Juvenile hake & $3.63 \mathrm{E}-03$ & $3.81 \mathrm{E}-03$ & +14.11 & +17.27 & +5.37 & +10.76 \\
\hline Adult hake & $3.29 \mathrm{E}-03$ & $3.52 \mathrm{E}-03$ & +14.28 & +12.15 & +0.83 & +5.99 \\
\hline Blue whiting & $2.23 \mathrm{E}-03$ & $2.40 \mathrm{E}-03$ & +24.99 & +19.37 & -3.66 & +7.61 \\
\hline Demersal fishes (1) & $3.59 \mathrm{E}-03$ & $3.48 \mathrm{E}-03$ & -0.52 & -1.67 & -1.68 & -1.34 \\
\hline Demersal fishes (2) & - & - & -0.56 & +13.41 & +8.79 & +7.28 \\
\hline Demersal fishes (3) & $1.50 \mathrm{E}-03$ & $1.50 \mathrm{E}-03$ & -0.67 & -8.31 & -3.85 & -5.53 \\
\hline Demersal sharks & 8.91E-03 & $8.71 \mathrm{E}-03$ & +22.13 & +4.13 & -13.02 & -1.76 \\
\hline Benthopelagic fishes & - & - & +41.50 & +35.90 & -4.75 & +13.23 \\
\hline European anchovy & $2.61 \mathrm{E}-03$ & $2.58 \mathrm{E}-03$ & +4.35 & -0.92 & -2.86 & -0.26 \\
\hline European pilchard & $4.19 \mathrm{E}-04$ & $7.26 \mathrm{E}-04$ & +10.83 & -8.19 & -17.56 & -12.77 \\
\hline Other small pelagic fishes & - & - & -68.52 & -36.22 & +11.40 & -14.13 \\
\hline Horse mackerel & - & - & -38.62 & -34.19 & +0.66 & -17.85 \\
\hline Mackerel & - & - & -85.43 & -79.48 & +1.58 & -39.42 \\
\hline Atlantic bonito & $4.43 \mathrm{E}-03$ & $5.49 \mathrm{E}-04$ & -66.61 & -78.52 & -18.74 & -50.90 \\
\hline Swordfish & $2.70 \mathrm{E}-02$ & $2.46 \mathrm{E}-02$ & -26.39 & -70.73 & -51.60 & -60.40 \\
\hline Tuna farmed & $2.41 \mathrm{E}-02$ & $5.79 \mathrm{E}-03$ & +2160.83 & +2160.83 & +571.88 & +1407.22 \\
\hline Tuna & $4.99 \mathrm{E}-02$ & $2.30 \mathrm{E}-02$ & +34.25 & -62.47 & -69.80 & -47.57 \\
\hline Loggerhead turtles & - & $5.00 \mathrm{E}-02$ & +11.84 & +15.64 & +4.19 & +10.45 \\
\hline Audouins gull & $2.66 \mathrm{E}-02$ & - & +1.40 & -12.04 & -12.21 & +12.33 \\
\hline Other sea birds & - & $2.66 \mathrm{E}-02$ & +8.86 & +20.57 & +9.91 & +14.97 \\
\hline Dolphins & $3.01 \mathrm{E}-02$ & - & -13.03 & -12.36 & +0.14 & -8.49 \\
\hline Fin whale & - & $3.03 E-02$ & +24.40 & +34.57 & +14.66 & +23.85 \\
\hline Discards 1 & $2.95 \mathrm{E}-03$ & - & +8.51 & +11.41 & +2.75 & +7.26 \\
\hline Discards 2 & $2.29 \mathrm{E}-04$ & $3.05 \mathrm{E}-03$ & +10.85 & +9.53 & +0.08 & +4.87 \\
\hline Fish farm feed & - & - & +357.38 & +532.47 & 218.76 & +521.24 \\
\hline Detritus & $2.29 \mathrm{E}-04$ & $2.14 \mathrm{E}-04$ & -0.02 & -0.73 & -0.78 & -0.68 \\
\hline
\end{tabular}

case with all the functional groups examined. Benthopelagic cephalopods experienced a slight increase in yield, though there was no large change in their biomass (Figs. 4 \& 5). Other small pelagic fish, horse mackerel, mackerel, Atlantic bonito, swordfish and wild tuna all exhibited different patterns in their yield.

Catch of other small pelagic fish, horse mackerel, mackerel and wild bluefin tuna catch were all greatly affected by the different scenarios. The degrees of decrease depended on the shifts to bluefin tuna quotas as the changes occurred in 2010. Mackerel and horse mackerel showed a parabolic change, first increasing and then decreasing according to different scenarios. Swordfish and Atlantic bonito showed a similar pattern of reduction, though Atlantic bonito was more sensitive to changes in the scenarios after 2010. Atlantic bonito yield was reduced across all scenarios, excluding Scenario 5, where an increase in catch was observed (Fig. 5). 

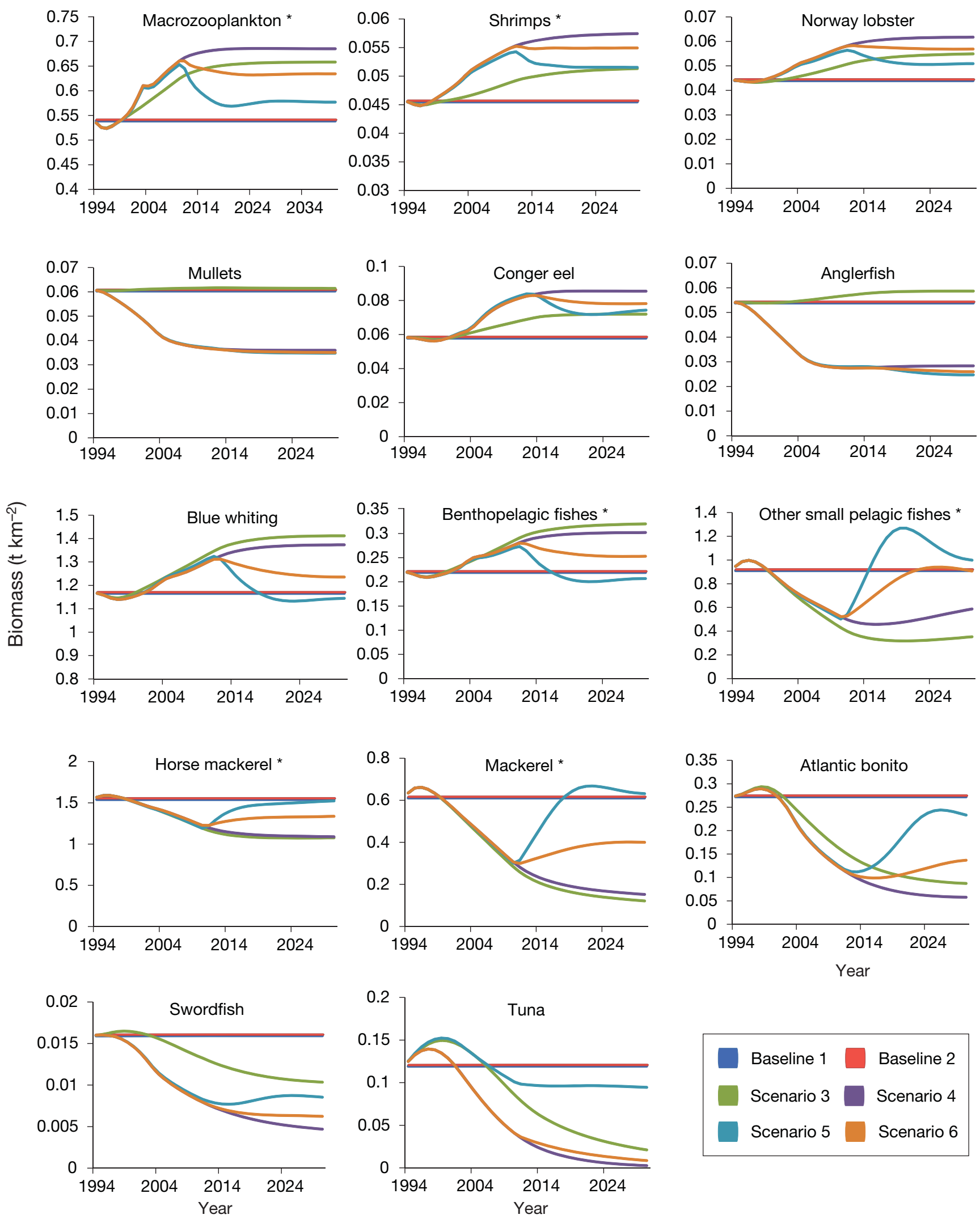

Fig. 4. Biomass $\left(\mathrm{t} \mathrm{km}^{-2}\right)$ changes of living functional groups by simulation. Asterisks designate prey/feed functional groups of bluefin tuna 

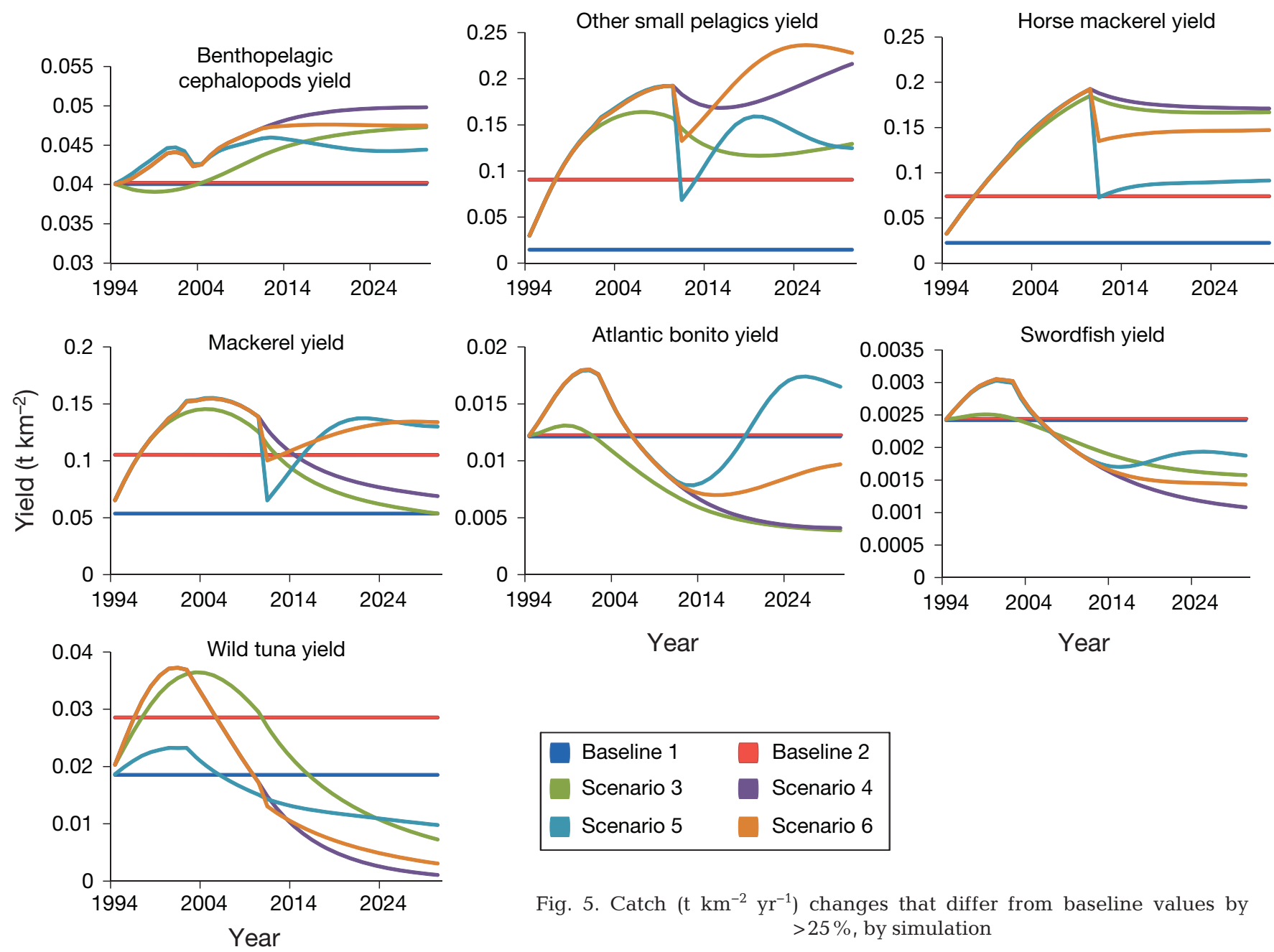

Fig. 5. Catch ( $\mathrm{t} \mathrm{km}^{-2} \mathrm{yr}^{-1}$ ) changes that differ from baseline values by $>25 \%$, by simulation

\section{Ecosystem changes}

Of the 14 functional groups representing the prey species for wild tuna in the ecosystem model, 7 groups did not show large changes in their biomass, regardless of an increase in fishing pressure and growth of the bluefin tuna cages. However, jellyfish increased in biomass across scenarios, as did benthopelagic fish, except in Scenario 5 (Table 4, Fig. 4).

Table 5. Changes in biomass by integer trophic level and by scenario (Table 1, Fig. 3). BL: Baseline; SC: Scenario

\begin{tabular}{|lccrrrr|}
\hline $\begin{array}{l}\text { Trophic } \\
\text { level }\end{array}$ & BL 1 & BL 2 & SC 3 & SC 4 & SC 5 & SC 6 \\
\hline$<$ III & 0.00 & 0.00 & 1.73 & 0.45 & -0.55 & -0.10 \\
III-IV & 0.00 & 0.00 & -13.36 & -12.15 & -0.82 & -5.53 \\
$>$ IV & 0.01 & 0.01 & -7.80 & -28.44 & -10.98 & -21.15 \\
\hline
\end{tabular}

Biomass levels were analyzed by grouping functional groups into integer trophic level ranges: II to III, III-IV and >IV. Trophic levels in the model, excluding TL I, ranged from polychaetes with $\mathrm{TL}=$ II to wild bluefin tuna with TL $=4.5$. Phytoplankton and detritus, with $\mathrm{TL}=\mathrm{I}$, were not included in the calculations since observed changes were small $(<2 \%)$ (Table 5$)$. The bulk $(80.17 \%)$ of the biomass in the initial model was comprised between TL II and TL III. Trophic levels between III and IV made up $18.03 \%$ of the biomass in the initial model, while $1.8 \%$ of the biomass was located in TL IV.

As a results of our simulations in Scenarios 3 to 6, the biomass of functional groups below TL III generally increased, with changes ranging between -0.55 and 1.73 (Table 4). In addition, the biomass of functional groups between TL III and TL IV decreased, with changes ranging between -0.82 and $-22.19 \%$. Functional groups in TL IV and above had the 
Table 6. Results of network analysis for all scenarios. TST: total system throughput; OF: overall flows; FCI: Finn cycling index; PL: path length; E: export; R: respiration; PP: primary production; TP: total production; TB: total biomass; TC: total catch; FD: proportion of flows to detritus; A: ascendency

\begin{tabular}{|c|c|c|c|c|c|c|}
\hline & Baseline 1 & Baseline 2 & Scenario 3 & Scenario 4 & Scenario 5 & Scenario 6 \\
\hline TST $\left(\mathrm{t} \mathrm{km}{ }^{-2} \mathrm{yr}^{-1}\right)$ & 3041.14 & 3041.62 & 3059.71 & 3064.78 & 3052.86 & 3059.29 \\
\hline $\mathrm{OF}\left(\mathrm{t} \mathrm{km}^{-2} \mathrm{yr}^{-1}\right)$ & 55.58 & 55.53 & 54.70 & 54.85 & 55.33 & 55.05 \\
\hline FCI $(\%)$ & 11.59 & 11.58 & 11.51 & 11.56 & 11.59 & 11.57 \\
\hline PL & 5.21 & 5.21 & 5.17 & 5.17 & 5.19 & 5.17 \\
\hline $\mathrm{E}\left(\mathrm{t} \mathrm{km} \mathrm{km}^{-2} \mathrm{yr}^{-1}\right)$ & 24.60 & 24.86 & 25.40 & 25.43 & 24.94 & 25.26 \\
\hline $\mathrm{R}\left(\mathrm{t} \mathrm{km}^{-2} \mathrm{yr}^{-1}\right)$ & 559.02 & 559.20 & 566.64 & 567.91 & 563.52 & 565.99 \\
\hline $\mathrm{PP}\left(\mathrm{t} \mathrm{km}^{-2} \mathrm{yr}^{-1}\right)$ & 1577.00 & 1577.00 & 1576.50 & 1570.86 & 1572.56 & 1572.13 \\
\hline $\mathrm{TP}\left(\mathrm{t} \mathrm{km}^{-2} \mathrm{yr}^{-1}\right)$ & 1851.30 & 1851.31 & 1853.17 & 1850.09 & 1849.36 & 1849.94 \\
\hline $\mathrm{TB}\left(\mathrm{t} \mathrm{km}^{-2}\right)$ & 58.98 & 59.01 & 59.05 & 58.40 & 58.84 & 58.66 \\
\hline $\mathrm{TC}\left(\mathrm{t} \mathrm{km} \mathrm{km}^{-2} \mathrm{yr}^{-1}\right)$ & 5.34 & 5.53 & 6.09 & 6.12 & 5.63 & 5.94 \\
\hline FD & 0.31 & 0.31 & 0.32 & 0.32 & 0.31 & 0.32 \\
\hline A & 2790.44 & 2793.84 & 2899.10 & 2889.21 & 2825.51 & 2861.36 \\
\hline
\end{tabular}

largest range of change, although they represented the smallest part of the total biomass $1.8 \%$.

Results regarding changes of ecosystem indicators for the 5 scenarios compared with the trends that would be expected from an ecosystem undergoing degradation (Table 6) show that of the 12 indicators examined, 10 showed trends that were consistent with degradation of the ecosystem (Table 6). The indicators consistent with degradation included a decrease in $\mathrm{TB}$ and an increase in $\mathrm{TC}$, a reduction in OF, and a decrease in the FCI, percent and PL. Other network analyses that were consistent with degradation were seen in increases in $\mathrm{E}, \mathrm{R}, \mathrm{TP}, \mathrm{FD}$ and $\mathrm{A}$ (Christensen et al. 2008) (Table 6).

\section{DISCUSSION}

\section{Parameterization of the tuna model and dynamic simulations}

The original southern Catalan model used here (Coll et al. 2006) was assessed using the pedigree index, a widely used method to assess model quality (Christensen \& Walters 2004). The highest pedigree index values represent data that were found through precise measurements or empirical equations for the area of study. The pedigree index value for the Catalan Sea model was 0.670, a high value when compared to other pedigree values for previously constructed models, which range from 0.164 to 0.676 (Morissette 2007). The bluefin tuna Thunnus thynnus thynnus biomass data incorporated in the modified model was obtained from the study of one farm with a bluefin tuna holding capacity of around $400 \mathrm{t}$, the average cage capacity in Spain.
The local origin of the new data maintained the quality of the model (with a re-calculated pedigree index of 0.685).

Although our results present plausible scenarios of fattening developments, the largest bluefin tuna operators in Spain reported to the ICCAT capacities of up to $1000 \mathrm{t}$ of bluefin tuna, so their impacts on the system could be larger. The grow-out time period varies from region to region; however, the longest time bluefin tuna are kept in cages is in Croatia, with a grow-out period lasting over a year (Ottolenghi 2008). There are few published studies on growth of bluefin tuna while in farms, and accurate data are scarce on how many bluefin tuna are actually stocked in cages; thus, these regional differences in parameters may affect our results.

The production to biomass ratio $(P / B)$ is slightly higher for farm bluefin tuna than for wild bluefin tuna $(0.275$ and 0.265 , respectively), while the food consumption per biomass estimate is almost 5 times higher than the $Q / B$ found through the empirical equation for wild bluefin tuna. The wild bluefin tuna $Q / B$ is $1.627 \mathrm{yr}^{-1}$, which is comparable to a previous estimate of $1.06 \mathrm{yr}^{-1}$ for Thunnus thynnus, found using multiple regressions (Palomares \& Pauly 1989). The larger estimate of $Q / B$ used in the Ecopath model is to be expected, since the bluefin tuna are consuming a greater amount of food than they would in the wild, as they are specifically being raised for increased weight and biomass, as well as fat content percentage. Estimates of daily consumption of bluefin tuna in the wild have ranged from 1.0 to $4.7 \%$ of their body weight, though it is difficult to specify exact amounts as the fish have a tendency to regurgitate their stomach contents upon capture (Overholtz 2006). 
The feed to the bluefin tuna cages represents the largest input of biomass to the cages. In the study by Aguado et al. (2004), the feed is roughly 2 times the tonnage that the cages produce. For the feed inputs to the cage the assumption was made that all of the feed was sourced from the Catalan Sea. In reality, the feed species were frozen baitfish that was sourced from several different ecosystems, including the Pacific in the case of mackerel. As such, the model represents what could possibly occur if most of the feed were sourced from one area, but including imports as resources from that area become insufficient. In reality some of the ecosystem effects modeled here would be dissipated to other ecosystems from which bluefin tuna feed is being sourced. Thus, it can be assumed that other ecosystems are subsidizing the costs of growing bluefin tuna in the western Mediterranean.

In a way, our simulations assume that all external conditions acting upon these migratory groups are in stationary equilibrium. It is well known that this is not the case; bluefin tuna farming dynamics and the management of bluefin tuna stock elsewhere in the Mediterranean are done at a much larger scale than that represented in the model. If management efforts are not successful, fewer bluefin tuna will be available in the Catalan Sea to stock the cages and declines of the wild stock in the Catalan Sea related to caging will be even greater. The same can be said about other predators that migrate, such as the Atlantic bonito, or those that depend on the same prey as bluefin tuna such as seabird species. Increase in cage culture of bluefin tuna throughout the Mediterranean will certainly lead to increased demand for small pelagic fish to feed the caged fish and fewer prey available for migrating seabirds, bonito and swordfish.

Finally, although our simulations were built using a model that had been previously fitted to data and thus hindcasting capabilities were assessed, our simulations do not explicitly include uncertainty of input parameters, since the aim of the study was to evaluate trends and our hypothesis. Additional inputs on parameter distributions and uncertainty would be highly relevant to provide reference levels and specific estimates for management.

\section{Bluefin tuna aquaculture in the Mediterranean Sea}

Taking into account previous data limitations and considerations, our results illustrate the potential negative impacts that a growing development of tuna aquaculture could have on Mediterranean marine ecosystems. For example, we observed that a decline of several demersal and pelagic commercial and noncommercial species may occur in parallel with an increase of smaller and higher turnover rate organisms such as jellyfish and benthopelagic fish. However, a model cannot capture all direct and indirect effects of overfishing, and impacts that are not trophic related are omitted. Therefore, the present study may be underestimating the impacts that aquaculture of bluefin tuna could have in Mediterranean waters. At the same time, our study is not informative on the effects that aquaculture activity may have on the overall Atlantic bluefin tuna stock, since this stock is widely distributed throughout the eastern Atlantic and Mediterranean Sea.

The goal in most capture-based aquaculture of bluefin tuna is not to increase the biomass levels, but rather the fat content in the bluefin tuna, thereby increasing the value of a single fish at the market place (Ottolenghi 2008). Albeit highly controversial, this practice is considered 'value-added fisheries'. The bluefin tuna farm used in the model was following this goal, as the biomass in the cages did not greatly increase during the fattening period, from 0.100 to $0.106 \mathrm{t} \mathrm{km}^{-2}$. If the goal of the bluefin tuna farm examined for the model differed from that of fat content accumulation, the effects on the ecosystem could have theoretically been greater due to the greater length of time the bluefin tuna would have to be kept in the cages. Additionally, bluefin tuna kept for longer periods of time are stocked as juveniles, which would shift fishing effort to smaller individuals. On the other hand, the diet of younger bluefin tuna may be more similar between wild and caged bluefin tuna, in terms of trophic level, and young caged bluefin tuna may only differ from young wild bluefin tuna in their daily rations.

Our modeling exercise did not address localized impacts of cages, such as impacts to the benthic community below the cages or to the biological communities in the surrounding water column due to direct impacts of shading or oxygen depletion. Several studies have looked into the effects of metabolic waste produced from bluefin tuna farms to benthic communities, sedimentation rates and nutrient cycling (e.g. Vezzulli et al. 2008, Lauer et al. 2009). While waste from aquaculture facilities has been cited as one of the main environmental concerns from the intensification of farming activities, the placement of cages in exposed, offshore locations is seen as a way to mitigate these effects (Vita et al. 2004). Bluefin tuna cages in the Mediterranean are 
typically placed in exposed locations for this reason; however, due to the unique nature of bluefin tuna cages, high stocking densities and a high feed conversion ratio have led to concern that these cages may have a greater impact than other culture operations in the region. Bluefin tuna farms in the Mediterranean have been associated with sedimentation rates near the operations an order of magnitude higher than the background environment (Vita et al. 2004).

Our study suggests that for bluefin tuna aquaculture to become a sustainable practice it may have to address concerns regarding the ecosystem impacts of harvesting feed and of capturing the wild bluefin tuna needed to stock and maintain fish in cages (Fig. 2). Shifting the reliance from frozen baitfish to an artificial diet of pellets could largely alleviate some of the effects seen by the increase of bluefin tuna production in the experimental scenarios modeled. Although extensive research on artificial feed has been conducted, especially for southern bluefin tuna Thunnus maccoyii, a reliable and economic artificial feed is still to be developed. There is some hope in the fact that the life-cycle of the Pacific bluefin tuna $T$. orientalis was successfully closed in captivity by researchers at Kinki University in Japan; however, production of juveniles at the volume needed for large commercial operations has yet to be attained (Sawada et al. 2005). Efforts toward captive spawning in the cages have been made in Italy and Spain with some success in hatching; nevertheless, larval rearing still remains a challenge (Mylonas et al. 2010).

In the near future, the continued reliance on wild populations of bluefin tuna to supply market demands and farms will likely lead to further removal of these top predators from ecosystems throughout the North Atlantic and Mediterranean. Several studies have exhibited the cascading effects that these removals can have on various ecosystems (Jackson et al. 2001, Pauly et al. 2009). Future examinations of bluefin tuna farming at the ecosystem level should also focus on modeling the effects on surrounding ecosystems. As the southern Catalan Sea is not a closed ecosystem, the effects seen in the model may have implications for nearby ecosystems. The model used in the present study assumed that the bluefin tuna were partially sourced from the modeled area, as well as a large amount of the feed species. In reality, the bluefin tuna stocked in the cages are sourced from all over the Mediterranean, and, due to their migration patterns, their removal could have farreaching effects, which would be difficult to capture without a global model of the Mediterranean Basin. The feed species are sourced from ecosystems worldwide, and the removal of these small pelagic species should be examined for different ecosystems, in particular for highly productive upwelling systems.

\section{Ecosystem effects of bluefin tuna aquaculture in the Mediterranean Sea}

The removal of apex predators through fishing mortality can have similar effects to those observed in other studies where removal of top predators impacted lower trophic level organisms. For example, the cod fishery in the northwestern Atlantic experienced a collapse in the late 1980s and early 1990s, and the removal of cod caused an increase in biomass levels of benthic invertebrates and small pelagic fish species (Frank et al. 2005). These studies highlighted that fishing at top levels can have unforeseen outcomes on the structure of the ecosystem, due to the complexity of the food web. Aquaculture at top levels can increase this complexity, adding additional ecosystem effects.

The continued reliance on wild populations of bluefin, without adequate management, to supply the demands of the market will continue to lead to removal of these top predators from ecosystems throughout the North Atlantic and Mediterranean. While an increase in certain crustacean species may be beneficial to the economy of the region, particularly in the case of Norway lobster, other functional groups are not as beneficial. In our study, biomass of both jellyfish and benthopelagic fish were projected to increase. These 2 groups are known as indicators of ecosystem change and show a change in the trophic structure towards low-trophic-energy food webs (e.g. Coll et al. 2006, Pauly et al. 2009). They could also have negative effects on the fishing and tourism industries. Moreover, high levels of aquaculture showed increasing degradation of the ecosystem structure to shorter, flatter and less complex food webs. This should be taken into account when planning and evaluating aquaculture activities in marine ecosystems, especially in the context of the Mediterranean Sea, which is already highly threatened (Stergiou et al. 2009, Coll et al. 2010, Costello et al. 2010).

\section{CONCLUSIONS}

Based on a food-web model of the southern Catalan Sea (northwestern Mediterranean), the current 
study presented evidence that bluefin tuna farming has impacts on marine ecosystems that should be taken into account when evaluating the sustainability of this industry. At present, the future of bluefin tuna fishing and trade is evaluated exclusively on the basis of the bluefin tuna stock. Both within the CITES and management context, ecosystem effects are not explicitly considered in management decisions. Here evidence is presented that such decisions cannot be made isolated from ecosystem effects. Management of bluefin tuna, including the choice of whether the bluefin harvest TAC is directed towards fishery landings or stocking of cages, can have significant effects on the local ecosystems. These effects are detectable in both the benthic and pelagic sub-systems and may affect many other species under management such as swordfish, bonito, Norway lobster and mackerels. The effects are important, especially in highly threatened ecosystems. The present study suggests that in the northwestern Mediterranean Sea, increasing bluefin tuna farming activities may contribute towards further degradation of ecosystems, with depletion of higher trophic level organisms and an increase of smaller organisms' biomass.

Acknowledgements. We acknowledge the co-authors of the southern Catalan Sea model used in this study: Isabel Palomera, Sergi Tudela and Siscu Sardà. We are also thankful to the Fisheries Centre (University of British Columbia, Vancouver, Canada), which facilitated this study, and to our colleagues Chiara Piroddi and Pablo Trujillo for their contributions to the discussion of aquaculture impacts. We also thank 2 anonymous reviewers for their comments as well as Ian Enochs for his assistance in developing figures. M.C. was supported financially by the European Community Marie-Curie post-doctoral fellowship through the International Outgoing Fellowships (IOF; Call: FP7-PEOPLE-20074-1-IOF) to ECOFUN.

\section{LITERATURE CITED}

Aguado F, Martinez FJ, Garcia-Garcia B (2004) In vivo total nitrogen and total phosphorous digestibility in Atlantic bluefin tuna (Thunnus thynnus thynnus Linnaeus, 1758) under industrially intensive fattening conditions in Southeast Spain Mediterranean coastal waters. Aquacult Nutr 10:413-419

> Aguado-Gimenez, F, Garcia-Garcia B, Hernandez-Lorente MD, Cerezo-Valverde J (2006) Gross metabolic waste output estimates using a nutritional approach in Atlantic bluefin tuna (Thunnus thynnus) under intensive fattening conditions in western Mediterranean Sea. Aquacult Res 37:1254-1258

Aguado-Gimenez F, Garcia-Garcia B (2005) Growth, food intake, and feed conversion rates in captive Atlantic bluefin tuna (Thunnus thynnus Linnaeus, 1758) under fattening conditions. Aquacult Res 36:610-614
Ahrens RNM, Walters CJ, Christensen V (2011) Foraging arena theory. Fish Fish 13:41-59

Allen RR (1971) Relation between production and biomass. J Fish Res Board Can 28:1573-1581

> Araujo JN, Mackinson S, Stanford RJ, Hart PJB (2008) Exploring fisheries strategies for the western English Channel using an ecosystem model. Ecol Model 210: 465-477

Casini M, Hjelm J, Molinero JC, Lovgren J and others (2009) Trophic cascades promote threshold-like shifts in pelagic marine ecosystems. Proc Natl Acad Sci USA 106:197-202

Christensen V, Maclean J (eds) (2011) Ecosystem approaches to fisheries - A global perspective. Cambridge University Press, Cambridge

Christensen V, Pauly D (1993) Trophic models of aquatic ecosystems. ICLARM Conf Proc 26

> Christensen V, Pauly D (2004) Placing fisheries in their ecosystem context, an introduction. Ecol Model 172: 103-107

> Christensen V, Walters CJ (2004) Ecopath with Ecosim: methods, capabilities and limitations. Ecol Model 172: 109-139

Christensen V, Walters C, Pauly D, Forrest R (2008) Ecopath with Ecosim, Version 6. User's guide-November 2008. Lenfest Ocean Futures Project 2008, ftp://ftp.fisheries. ubc.ca/ecopath/webfiles/ewe6/Documentation/Ewe\%20 User\%20Guide\%206.pdf

CITES (Convention on International Trade of Endangered Species of Wild Fauna and Flora) (2010) Proposal to include Atlantic bluefin tuna (Thunnus thynnus [Linnaeus, 1758]) on Appendix I of CITES in accordance with Article II 1 of the Convention. CoP15 Prop. 19, 15th meeting of the conference of the parties. Doha (Qatar), 13-25 March 2010

Coll M, Libralato S (2012) Contributions of food-web modelling for an ecosystem approach to marine resources in the Mediterranean Sea. Fish Fish 13:60-88

> Coll M, Palomera I, Tudela S, Sardà F (2006) Trophic flows, ecosystem structure and fishing impacts in the South Catalan Sea, northwestern Mediterranean. J Mar Syst 59:63-96

Coll M, Santojanni A, Palomera I, Tudela S, Arneri E (2007) An ecological model of the northern and central Adriatic Sea: analysis of ecosystem structure and fishing impacts. J Mar Syst 67:119-154

> Coll M, Palomera I, Tudela S, Dowd M (2008) Food-web dynamics in the South Catalan Sea ecosystem (NW Mediterranean) for 1978-2003. Ecol Model 217:95-116

Coll M, Piroddi C, Kaschner K, Ben Rais Lasram F and others (2010) The biodiversity of the Mediterranean Sea: estimates, patterns and threats. PLoS ONE 5:e11842

Coll M, Piroddi C, Albouy C, Ben Rais Lasram F and others (2012) The Mediterranean Sea under siege: spatial overlap between marine biodiversity, cumulative threats and marine reserves. Glob Ecol Biogeogr 21:465-480

> Costello MJ, Coll M, Danovaro R, Halpin P, Ojaveer H, Miloslavich P (2010) A census of marine biodiversity knowledge, resources and future challenges. PLoS ONE 5:e12110

> Cury P, Bakun A, Crawford RJM, Jarre A, Quinones RA, Shannon LJ, Verheye HM (2000) Small pelagics in upwelling systems: patterns of interaction and structural changes in 'wasp-waist' ecosystems. ICES J Mar Sci 57: 603-618

FAO (Food and Agriculture Organization) (2003) The eco- 
system approach to fisheries. FAO technical guidelines for responsible fisheries No. 4, Suppl. 2. FAO, Rome

Frank KT, Petrie B, Choy JS, Leggett WC (2005) Trophic cascades in a formerly cod-dominated ecosystem. Science 308:1621-1623

Fulton EA, Smith ADM (2004) Lessons learnt from a comparison of three ecosystem models for Port Phillip Bay, Australia. Afr J Mar Sci 26:219-243

ICCAT (International Commission for the Conservation of Atlantic Tunas) (2011) Report of the 2010 Atlantic bluefin tuna stock assessment session. Collect Vol Sci Pap ICCAT 66:505-714

Jackson JBC, Kirby MX, Berger WH, Bjorndal KA and others (2001) Historical overfishing and the recent collapse of coastal ecosystems. Science 293:629-638

Lauer PR, Fernandes M, Fairweather PG, Tanner J, Cheshire A (2009) Benthic fluxes of nitrogen and phosphorous at southern bluefin tuna Thynnus maccoyii seacages. Mar Ecol Prog Ser 390:251-263

MacKenzie BR, Mosegaard H, Rosenberg AA (2009) Impending collapse of bluefin tuna in the northeast Atlantic and Mediterranean. Conserv Lett 2:26-35

Miyake PM, De la Serna JM, Di Natale A, Farrugia A, Katavic I, Miyabe N, Ticina V (2003) General overview of bluefin tuna farming in the Mediterranean area. ICCAT Sci Pap 55:114-124

Morissette L (2007) Complexity, cost and quality of ecosystem models and their impact on resilience: a comparative analysis, with emphasis on marine mammals and the Gulf of St. Lawrence. PhD thesis, University of British Columbia, Vancouver

Mylonas CC, De La Gandara F, Corriero A, Rios AB (2010) Atlantic bluefin tuna (Thunnus thynnus) farming and fattening in the Mediterranean Sea. Rev Fish Sci 18: 266-280

Ottolenghi F (2004) Capture-based aquaculture: the fattening of eels, groupers, tunas and yellowtails. FAO, Rome

Ottolenghi F (2008) Capture-based aquaculture of bluefin tuna. FAO Fish Tech Pap 508:169-182

> Overholtz WJ (2006) Estimates of consumption of Atlantic herring (Clupea harengus) by bluefin tuna (Thunnus thynnus) during 1970-2002: an approach incorporating uncertainty. J Northw Atl Fish Sci 36:55-63

Palomares ML, Pauly D (1989) A multiple regression model for predicting the food consumption of marine fish populations. Aust J Mar Freshw Res 40:259-273

Palomares MLD, Morissette L, Cisneros-Montemayor A, Varkey D, Coll M, Piroddi C (2009) Ecopath 25 Years con- ference: extended abstracts. Fish Cent Res Rep 17:171

> Pauly D, Christensen V, Walters C (2000) Ecopath, Ecosim and Ecospace as tools for evaluating ecosystem impact of fisheries. ICES J Mar Sci 57:697-706

> Pauly D, Graham W, Libralato S, Morissette L, Palomares MLD (2009) Jellyfish in ecosystems, online databases, and ecosystem models. Hydrobiologia 616:67-85

Piroddi C (2008) The application of Ecopath with Ecosim to the study of two populations of dolphins in the eastern Ionian Sea, Greece. MSc thesis, University of British Columbia, Vancouver

Plagányi ÉE (2007) Models for an ecosystem approach to fisheries. FAO Fish Tech Pap 477

Plagányi ÉE, Butterworth DS (2004) A critical look at the potential of Ecopath with Ecosim to assist in practical fisheries management. Afr J Mar Sci 26:261-287

Polovina JJ (1984) Model of a coral reef ecosystem. I. The Ecopath model and its application to French frigate shoals. Coral Reefs 3:1-11

Porch CE (2005) The sustainability of western Atlantic bluefin tuna: a warm-blooded fish in a hot-blooded fishery. Bull Mar Sci 76:363-384

Salomon AK, Gaichas SK, Shears NT, Smith JE, Madin EMP, Gaines SD (2010) Key features and context-dependence of fishery-induced trophic cascades. Conserv Biol 24: 382-394

> Sawada Y, Okada T, Miyashita S, Murata O, Kumai H (2005) Completion of the Pacific bluefin tuna Thunnus orientalis (Temminck et Schlegel) life cycle. Aquacult Res 36: 413-421

> Stergiou KI, Tsikliras AC, Pauly D (2009) Farming up Mediterranean food webs. Conserv Biol 23:230-232

> Vezzulli L, Moreno M, Marin V, Pezzati E, Bartoli M, Fabiano M (2008) Organic waste impact of capture-based Atlantic bluefin tuna aquaculture at an exposed site in the Mediterranean Sea. Estuar Coast Shelf Sci 78: 369-384

> Vita R, Marin A, Madrid JA, Jimenez-Brinquis B, Cesar A, Marin-Guirao L (2004) Effects of wild fishes on waste exportation from a Mediterranean fish farm. Mar Ecol Prog Ser 277:253-261

Walters CJ, Christensen V, Pauly D (1997) Structuring dynamic models of exploited ecosystems from trophic mass-balance assessments. Rev Fish Biol Fish 7:139-172

WWF (World Wildlife Fund) (2005) Risk on local fish populations and ecosystems posed by the use of imported feed fish by the tuna farming industry in the Mediterranean. WWF Mediterranean Programme, Barcelona 
Appendix 1. Description of the Ecopath with Ecosim modeling approach and application to the Catalan Sea.

We used Ecopath Version 6 to ensure energy balance of the model (Christensen et al. 2008):

$$
P_{1}=\sum_{j} B_{j} \cdot M 2_{i j}+Y_{i}+E_{i}+B A_{i}+P_{i} \cdot\left(1-E E_{i}\right)
$$

where the production $(P)$ of the ith component, or functional group, of the ecosystem is divided into predation mortality $\left(M 2_{i j}\right)$ caused by the biomass of the other predators $\left(B_{j}\right)_{\text {; }}$ exports from the system both from fishing catches $\left(Y_{i}\right)$ and emigration $\left(E_{i}\right)_{i}$ biomass accumulation in the ecosystem $\left(B A_{i}\right)$; and other mortality or mortality not captured by the model $\left(1-E E_{i}\right)$. $E E_{i}$ is the ecotrophic efficiency of the group within the system, or the proportion of the production $P_{i}$ that is exported out of the ecosystem (i.e. by fishing activity) or consumed by predators within it. Eq. (1) can be re-expressed as:

$B \cdot(P / B)_{i}=$

$\sum_{j} B_{j} \cdot(Q / B)_{j} \cdot D C_{i j}+Y_{i}+E_{i}+B A_{j}+B_{i} \cdot(P / B)_{i} \cdot\left(1-E E_{i}\right)$

where $(P / B)_{i}$ indicates the production of $i$ per unit of biomass and is equivalent to total mortality, or $Z$, under steady-state conditions (Allen 1971); $(Q / B)_{i}$ is the consumption of $i$ per unit of biomass; and $D C_{i j}$ indicates the proportion of $i$ that is in the diet of predator $j$ in terms of volume or weight units.

EwE parameterizes the model by describing a system of linear equations for all the functional groups in the model, where for each equation at least 3 of the basic parameters: $B_{i r}(P / B)_{i r}(Q / B)_{i r}$ or $E E_{i}$ have to be known for each group $i$, in addition to the diet composition. The energy balance within each group is ensured when consumption by group $i$ equals production by $i$, respiration by $i$ and food that is unassimilated by $i$. A review of the Ecopath with Ecosim approach, capabilities and limitations can be found in Christensen \& Walters (2004), Fulton \& Smith (2004) and Plagányi \& Butterworth (2004).

From Ecopath, the base model, both temporal and spatial simulations can be conducted using the time and spatial dynamic modules Ecosim and Ecospace, respectively. Ecosim uses a system of time-dependent differential equations from the baseline mass-balance model where the growth rate of biomass is expressed as:

$\mathrm{d} B_{i} / \mathrm{d} t=(P / Q)_{i} \cdot \sum Q_{j i}-\sum Q_{j i}+I_{i}-\left(M_{i}+F_{i}+e_{i}\right) \cdot B_{i}$

where $(P / Q)_{i}$ is the gross efficiency; $M_{i}$ is the non-predation natural mortality rate; $F_{i}$ is the fishing mortality rate; $e_{i}$ is the emigration rate; $I_{i}$ is the immigration rate; and $B_{i}$ is the biomass of the functional group $i$. Calculations of consumption rates $\left(Q_{i j}\right)$ are based upon the 'foraging arena' theory (Ahrens et al. 2011), where the biomass of prey $i$ is divided between a vulnerable and a non-vulnerable fraction. Ecosim simulations are especially sensitive to the 'vulnerability' settings, which incorporate density-dependency and express how far a group is from its carrying capacity (Christensen \& Walters 2004, Christensen et al. 2008). Therefore, fitting the model to data is advised before performing simulations.

In the present study we modified an existing Ecopath model representing an exploited ecosystem of the northwestern Mediterranean Sea (Coll et al. 2006) previously fitted to time series of data (Coll et al. 2008), and we included the presence of capture-based tuna aquaculture. The Ecopath model was re-parameterized and was used to develop temporal simulations to evaluate the ecosystem effects of capture-based tuna aquaculture activities.
Editorial responsibility: Konstantinos Stergiou, Thessaloniki, Greece
Submitted: July 7, 2011; Accepted: March 3, 2012

Proofs received from author(s): May 25, 2012 